\title{
Monastic Investment Bootstrapping: An Economic Model for the Expansion of Early Buddhism
}

\author{
MATTHEW D. MILLIGAN \\ Trinity University \\ mattdmilligan@gmail.com
}

Keywords: monasticism, bootstrapping, patronage, venture capitalism, wealth, Sanchi

DOI: https://dx.doi.org/10.15239/hijbs.02.02.04

Abstract: This paper borrows from recent trends in business finance (namely venture capitalism) to begin theorizing a model for the spread of Buddhism outside of the Buddha's homeland in ancient Magadha. During the Early Historic Period (300 BCE-300 CE) in South Asia, dozens of new Buddhist pilgrimage sites emerged centered on stūpas, the relics of the Buddha and prominent Buddhist saints. At many of these sites, donor records were etched into stone, thus creating a roster of some of the earliest financiers to the burgeoning Buddhist monastic institution. I sifted through these donor records to examine just who these early patrons were, where they came from, and potentially what their aims were in funding a new religious movement. Not only did the donative investment records exist for posterity, meaning for the sake of future investors to the Buddhist samgha, but they also served as markers of ongoing financial success. If the old adage holds true, that it takes money to make money, then whose money did the early samgha utilize to create its image of success for future investors? My research reveals that a majority of the investors to the samgha were the monastics themselves. 
Put simply, monks and nuns formed the largest and most authoritative patronage demographic from which they used their own personal wealth to, in essence, 'pull the samgha up by its bootstraps'. I argue that this phenomenon aligns closely with modern business creation and growth in the United States and elsewhere since many founding members of businesses and institutions often begin their endeavors with their own personal assets, including wealth, property, and/or loans.

\section{Introduction}

A lready more than twenty years ago, Gregory Schopen shed early Indian Buddhism: monastic Buddhists, as they self-identify in inscriptions from the last few centuries BCE, were listed, in multitudes, as frequent major donors to stūpa pilgrimage centers like Sanchi, Bharhut, and others. ${ }^{1}$ Although Schopen was not the first to notice this phenomenon whereby the premier ascetics from a śramanic tradition seemed to have a great deal of wealth, he was, to my knowledge, the first to recognize one very defining feature of these epigraphic records. To use his own words-which seem to be first published in 1992, and again in 1994, 1995, and 1996 in articles for several leading journals-monk and nun donors were listed and described 'exactly like laymen' in extant epigraphic corpora. $^{2}$ What he observed was that, at least in these plentiful donative inscriptions, monastic donors not only seemed to possess substantial wealth with which to gift but also self-identified their natal home residences instead of their home vihäras. Schopen's significant observation has since been scarcely re-emphasized or

1 There are many examples throughout Gregory Schopen's two collected volumes: Bones, Stones, and Buddhist Monks; Buddhist Monks and Business Matters.

2 Schopen, 'The Ritual Obligations', 77-78; Schopen, 'Doing Business', 550; Schopen, 'Monastic Law', 106; Schopen, 'The Lay Ownership'. 
re-contextualized, let alone, most remarkably, actually evaluated or supplemented. This paper serves as one such critical evaluation. I present some evidence to expand on Schopen's often-used remark and bring the conversation about monastic wealth and the economics of early Indian Buddhist renunciation forward insofar as the material evidence will allow.

Given the materially prosperous situation of numerous monastic Buddhists at the time of the construction and expansion of many large open-air stüpas in early historic South Asia, I ask the question: are we able to equate their propensity for accumulating and donating wealth with their status of being, in many ways, as Schopen said, 'exactly like laymen'? I hypothesize that a micro-history of the Sanchi stüpas allows us not only to answer this question with a great deal of confidence, but also to catch a small glimpse of the economic process at work in ancient central India, one of the first places Buddhism spread after the parinirvanna of the Buddha himself. In my best estimate, the phrase 'exactly like laymen' may better refer to the business model where lay and samgha both profit from the same types of donations. Evidence presented below will show how the early Indian Buddhist institution seemed to adopt a particular type of patronage model, which I call 'bootstrapping'. In a bootstrapping model, the monastic samgha, in their earliest stages of material expansion outside of Māgadha, self-funded their own monuments in order to attract future wealthy non-monastic lay donors.

\section{Sanchi-Context and Dating}

The setting for this micro-history is not at a particularly surprising location. Sanchi, located in modern-day Madhya Pradesh, was-and still is-a long-inhabited stüpa pilgrimage site, which probably began during the Mauryan period in the late third century BCE, as evidenced by the Aśokan pillar featuring a version of the famous schism edict to the south of the main stūpa's entrance. Although likely begun during the Mauryas, minus the core of the Great Stūpa, the extant material evidence from Sanchi does not begin until the late second century BCE or even early first century 
BCE. ${ }^{3}$ Nevertheless, Sanchi is well-known for its highly ornamented torana gateway reliefs and also, at least for some scholars, because of its large corpus of brābmī epigraphy spread across several monuments. This may be the largest single repository of early Buddhist epigraphic data in South Asia, with the exception potentially being clustered kharosthi $i$ graffiti from Gandhara. The extant epigraphic corpus-numbering more than 700-is, as Schopen and others pointed out, exceptionally helpful for analyzing some aspects of early Indian Buddhist social life, institutional history, population demographics, and, perhaps, some philosophical values, as the inscribed records formulate a roster of patrons. As such, in this paper, I will only discuss the epigraphy and will leave associations and discussions of the large body of Buddhist literature, including the Vinaya, for a separate investigation.

Further, to enhance the micro-analysis, I focus only on the time period in which most of the inscriptions probably date, which is the middle of the first century BCE. Sanchi is merely one historical case study with a rather large body of unique data that is only a representative sample of central Indian Buddhism. Future work may fruitfully connect this evidence for bootstrapping with the extant literary corpus as well as other similar sites yielding donation epigraphy such as Bharhut, Amaravati, Kanaganahalli, and the Western Deccan cave sites.

The process of dating the Sanchi site as a whole-although difficult-is fortunate to have a great deal of material with which to work. Essential to dating is the Aśokan pillar and its accompanying inscription, the reliquary inscriptions from stūpa 2, the relief art

3 For the excavation report, see Marshall, Foucher, and Majumdar, The Monuments of $S \bar{a} \tilde{n} c h \bar{i}$, vols. 1-3. However, for a detailed analysis of not only the archaeology, art, and surrounding regions, the work done by Julia Shaw and the Sanchi Survey Project is by far the most comprehensive to date: Shaw, Buddhist Landscapes in Central India. Beyond the Sanchi hilltop, there are dozens of smaller, but similar stūpa sites all originating to the Early Historic period. The extant epigraphy utilized in this essay has been more extensively analyzed in Milligan, 'Of Rags and Riches'. 
and accompanying inscriptions from the vedikās of stūpas 1 and 2 , and, of course, the monumental torana gateway art and inscriptions from stūpa 1. Although a thorough re-examination of all this evidence need not be worked out yet again here, we may tentatively summarize the Aśokan pillar and Aśokan brick layer in the stūpas as the terminus post quem (late third century BCE) ${ }^{4}$ for the initial era. ${ }^{5}$ The few ornate brābmī Kuṣāna and Gupta period inscriptions, which are either dated or contain references to rulers we may identify, formulate a soft terminus ad quem for the Early Historic period activity at Sanchi.

The epigraphy relevant to my paper dates to approximately the first century BCE. These inscriptions from stüpas one and two have nearly always been dated based on paleographic grounds, which are somewhat problematic, and on stūpa 2's artistic relationship with the Bharhut vedika and torana. Using this classic sequence as a starting point, in my dissertation and a recently published article, I was able to divide the epigraphy specifically from these two stūpas into two different eras that I label Generations. ${ }^{6}$ This dating was rooted in a relative chronology existing between the content of the inscriptions, ${ }^{7}$ especially the relationship between the donors themselves, according to the self-identified demographic data. The new, reassessed chronology I advocate for sequences the features as: Sanchi stūpa 2's vedikā as slightly later than Bharhut's vedikā and gateways, then stūpa 1's

4 While there could have been religious activity on the hilltop before Aśoka - and there probably was given the area's affinity for Nāga cults—the earliest buildings, such as the core of stūpa 1, were constructed using prototypical Aśokan bricks.

5 The brick core of stüpa 1 shares the same stratigraphic level as the foundations of the Aśokan pillar. The bricks of the core were also the prototypical Mauryan-sized bricks (16 x $10 \times 3$ in.). For a detailed and updated account of the archaeological dating as a whole, see Shaw, Buddhist Landscapes in Central India, 87.

6 See Milligan, 'Five Unnoticed Donative Inscriptions', 11-22; Milligan, 'Economic Power of Women'.

7 Milligan, 'Of Rags and Riches'. 
berm vedikā, which is likely contemporaneous with stūpa 1's berm vedika. Lastly, stüpa 1's famous toranas are later than all of them and are firmly dated to the early portion of the first century CE. Besides the art historical arguments to be made linking these monuments together, I also traced the donors themselves. Two donors, named Nāgapiya and Budharakhita, recur throughout, and if we use logic to think about their life spans, we can tentatively build a terminus post quem and a terminus ante quem for each of these monuments within the first century BCE. I hypothesize that the old chronology, that I only pushed back roughly half a century, used by scholars was mostly too ambitious in dating the majority of the inscriptions to the early or middle of the first century BCE. Instead, there is a strong relationship between the later torana inscriptions from stüpa 1 and the vedika inscriptions, thus implying that the chronology must be estimated more conservatively as being closer to the end of the first century BCE rather than the start. As such, what I call Generation 1 dates very likely to the middle of the first century BCE, while Generation 2 is one generation of donors later, maybe 30-50 years, toward the end of the first century BCE.

TABLE 1 Basic Epigraphic Tabulations

\begin{tabular}{lll}
\hline Era & Individual Donors & Total Donation Number \\
\hline Generation 1 & 209 & 244 \\
\hline Generation 2 & 292 & 362 \\
\hline
\end{tabular}

By using this division into two diachronic Generations, we may assess changes to the donation network over time. To begin, we may observe that the number of individual donors increases from 209 to 292, while the number of donations they generously give to the samgha also rises from 244 to 362 . What I deem an 'individual donor' is a single individual who may repeat his donation, thus resulting in having his or her name inscribed two or more times (which tallies into multiple donations from a single donor). From this core data, as I will demonstrate below, we can evaluate many 
aspects of the donation system as a whole from Generation 1 to Generation 2.

To begin diverging from what was explored by many previous scholars, who were interested only in the epigraphy, ${ }^{8}$ the relief art, ${ }^{9}$ or the architecture, ${ }^{10} \mathrm{I}$ attempted to figure a method of combining an investigation of the epigraphy with the art, architecture, and literature. ${ }^{11}$ Below, I explore one vital aspect of the relationship between the donation epigraphy and the architecture upon which it was inscribed. The gifts to the Sanchi samgha may have taken any number of forms, such as actual coins, property, animals, etc. However, there is limited art historical or archaeological evidence to explore donation on that level. The one exception that forms a representative sampling of donation to places like Sanchi are the vedika (monumental railing) fragments which became inscribed with donor names and social background. As such, it is crucial to study these individual architectural fragments that construct the specific monuments at Sanchi since they are the surviving physical manifestations of the generosity of the donor network's patrons. I propose that some qualities of the donation network may, therefore, be explored statistically by identifying the patterns of donation appearing on these architectural pieces with inscribed donor records. In particular, the remains that yielded donation epigraphy are cross-bars, rail-pillars, and coping-stones. Cross-bar inscriptions always appear in the central cross-bar of three stacked on top of one another (and in the middle of that bar); rail-pillar inscriptions appear at roughly human eye-level in the middle of the pillar; and the coping-stone inscriptions appear on the middle portion of the stone, which makes them difficult to assess let alone read and interpret from ground level.

8 Roy, 'Women and Men Donors'; Dehejia, 'The Collective and Popular Bases'; Schopen, 'What's in a Name?'.

9 Taddei, 'The First Beginnings'.

10 Shaw, 'Nāga Sculptures'; Shaw, Buddhist Landscapes in Central India.

11 Milligan, 'Of Rags and Riches'. 


\section{Bootstrapping}

With hundreds and even thousands of competitors in almost any modern-or, perhaps, also pre-modern-industry, bootstrapping is an integral part of starting a successful business. It can be quite tricky for individual entrepreneurs to find the capital they need for their business plan. Because of this, more and more entrepreneurs are donating their capital into the firm or company in order to get it off the ground. This phenomenon is the process of an entrepreneur or group of entrepreneurs within a company proverbially pulling themselves up by their bootstraps, as the phrase goes. However, bootstrapping does not pertain strictly to the initial donation process. There are several critical components to a successful bootstrap: (1) stretching resources beyond the initial donation phase in order to sustain the business; ${ }^{12}(2)$ not over-relying on only the resources by the initial donors by seeking out and cultivating social networks for alliances to tap into for additional donations; ${ }^{13}$ and (3) correctly utilizing existing capital, ${ }^{14}$ including human and social capital. ${ }^{15}$

As I argue throughout, the early Buddhist monastics at Sanchi seem to adhere to many of the sentiments found in these bootstrapping qualities. First, the epigraphic evidence we possess does not reveal the nascent samgha. Instead, the evidence shows a samgha that is in the process of maturing and developing new ways to sustain itself through the continued use of bootstrapping. Next, what is easily seen in the Sanchi epigraphy is a community of donors that are not entirely homogenous. That is, we see a roster of donors that are both monastic (i.e., part of the founding establishment) and non-monastic. Thus, the continued success of Sanchi is also reliant on alliances with the laity from near and far. Lastly, even though

\footnotetext{
12 Cornwall, Bootstrapping.

13 Jones and Jayawarna, 'Resourcing New Businesses'; Patel, Fiet, and Sohl, 'Mitigating the Limited Scalability of Bootstrapping'.

14 Grichnik et al., 'Beyond environmental scarcity'.

15 Jayawarna, Jones, and Macpherson, 'New Business Creation and Regional Development'.
} 
it is not within the primary scope of this current paper, many of the monastic donors at Sanchi are elite monks and nuns with a variety of esteemed titles, such as aya ('noble'), bhānaka ('reciter'), sutätikini ('versed in the suttas'), and pacanekayika ('knower of the five nikāyas'). Therefore, not only were these particular monastic donors elite with regard to their esteem within the community, but they were also charismatic teachers with their pupils, monastic and lay, who did, in fact, probably carry a great deal of social and so-called human capital with their identity, which likely instigated trust that they-or those they trust-would correctly manage the donated resources. All these factors point to a monastic institution that was poised to successfully and gradually materially expand from within - that is, bootstrap the Sanchi monuments.

\section{Valuation}

The stratification of the available number of potential gifts used to construct stüpa vedikās at places like Sanchi supports the notion that gifting (dāna) large material items may have increased the reputations of donors. The gift of an extremely large and weighty rail-pillar or coping-stone could have served as a substantial enhancer of reputation as donations only, not just as markers of the amount donated. Very few gifts are coping-stones at any given vedika, while there are throngs of cross-bar gifts. Gifting as a phenomenon is particularly apt in a religious community where not only can your social reputation increase from donation, but also you can simultaneously accrue some intangible, theological, or soteriological merit. ${ }^{16}$ In a book on giving in early Buddhism, E. B. Findly suggested that the conjunction of Buddhism and the newly emergent householder category of the era led to 'patrons of the [Buddhist] religion prosper[ing] socially in terms of their status and reputation, for dāna teachings tell potential donors that the more one gives, the greater ... their reputations' ${ }^{17}$

\footnotetext{
16 On exactly this process, see Schopen, 'What's in a Name?'.

17 Findly, Dāna, 17.
} 
This system allowed donors' worth to be based on merit-charity in this case-and not on birth. Later, Findly noted:

...the market-oriented culture, in which Buddhism emerges, reflects a shift away from the valuation of traditional duty and obligation and a more significant celebration of individual choice. This shift is based on the increased freedom brought about by social and economic changes and allows for individual initiative and creativity. It also means, however, in the case of renunciant petitioners, that householders are not obligated by preset affiliation to support them, as they are in Vedic settings. ${ }^{18}$

Therefore, the conscious choice to donate to the samgha at Sanchi seemed to allow for freedom in donation choice, as the donor was not forced to give something specific. There appears to be a wide range of possibilities to choose from, depending on the type of donation one sought to donate, which was at least partially dependent on socio-economic status as well as devotion to this particular religious community. The use of the word dana is viewed as an early synonym of the word deyadhamma, a religious donation, ${ }^{19}$ and perhaps both rail-pillars and coping-stones were donations of some repute.

A brief perusal of the Arthaśästra, ${ }^{20}$ the famous socio-economic textbook for kings compiled into its present form sometime between first century BCE and first century CE probably in a region between modern Maharashtra and Madhya Pradesh, reveals the approximate value of stone quarried from royally monopolized mines ${ }^{21}$ and how to measure such types of commodities. Initially, stone and ore

18 Findly, Dāna, 38.

19 In the western Deccan cave sites, the term deyadhamma (Pkt: 'religious/ meritorious gift') is frequently used in similar kinds of Buddhist donative inscriptions.

20 For a recent translation and discussion of details, including dating and geography of the text, see Olivelle, King, Governance, and Law. See, now, also McClish, The History of the Arthasiāstra.

21 AŚ 2.12.22. 
were officially valued according to their weights because, as the text says, as weight increases, so too does the metal content, with metal being something precious to the royal institution. ${ }^{22}$ Further, official state-sponsored weights utilized for measuring the value of everyday goods should be made of a stone from a particular location: Māgadha and Mekala. ${ }^{23}$ The text stated that if the stone used for an official standard state-endorsed weight was not from these localities, then it may be susceptible to manipulation by either adding water to make the stone-weight heavier or by heating it to decrease its weight.

Further, the Arthaśastra clearly elucidates the notion that the Superintendent of Customs (śulkādhyaksa) sets prices and sets up the sales of official commodities, like those products from royally monopolized mines and quarries, according to weight, measure, and/ or number, in direct contrast to articles of low value which should only be estimated-that is, not measured at all. ${ }^{24}$ That stone was precious as a construction material is evident, according to the text, since a good king should naturally build all state-sponsored fortifications with stone to guard against fire. ${ }^{25}$ Wood was not as valuable because it burns quickly and would be a tremendous liability. We may tentatively import this thinking to explain why the administrators who oversaw the construction of Sanchi chose to build and expand using such a heavy substance as stone, which undoubtedly required a significant amount of human resources to mine, move, and appropriately place.

Before nineteenth century Western scholarly and imperial investigation, Sanchi was pillaged for useful stone by local villagers who used it for farming and building activities. Many of its architectural pieces were lost. The remaining stone fragments are a vital source of information not only because of their extant nature, but because of the epigraphic records. Rail-pillars are the fundamental pieces available for donation. Two uprights hold together three cross-bars.

AŚ 2.12.7.

23 AŚ 2.19.10.

24 AŚ 2.22.8.

25 AŚ 2.3.8-9. 
Coping-stones are at the top of the rail-pillars and cap the vedik $\bar{a}$. There is a visual hierarchy to the naked eye between these three pieces. Coping-stones may be on top physically and are the largest, heaviest sections, but the standing rail-pillars are the most important functionally. Coping-stones and rail-pillars are complements to each other, as a coping-stone is merely a rail-pillar turned on its side.

There are at least three ways to think about the vedika architecture as it was constructed intellectually. First, functionally, we may consider each piece as an equal player in holding together the vedika, since a coping-stone operates as a cap while a rail-pillar supports the entire vedika from the base. Cross-bars enclose and align the visitor with the circumambulatory path. Second, we could think about the architecture symbolically. The coping-stone represents the grand scale of the vedik $\bar{a}$, since they are furthest from the ground despite being the heaviest. The rail-pillars represent the strength of the vedik $\bar{a}$, being that they uphold the coping-stones. Meanwhile, the cross-bars of the vedika effectively visually block a person's gaze by diverting the eyes back towards the immense stūpa. Similarly, the cross-bars restrict the view of the base of the stupa for those who are not walking in the circumambulatory path.

TABLE 2 Architectural Pieces of the Vedikā

\begin{tabular}{llllll}
\hline Feature & Location & Height & Width & Depth & Volume \\
\hline cross-bars & stūpa 1 & 28 in & 31 in & 3.5 in & $3038 \mathrm{in}^{3}$ \\
\hline rail-pillars & stūpa 1 & $101.5 \mathrm{in}$ & 26 in & $13.5 \mathrm{in}$ & $35626.5 \mathrm{in}^{3}$ \\
\hline coping-stones & stūpa 1 & 24 in & $110 \mathrm{in}$ & $24 \mathrm{in}$ & $63360 \mathrm{in}^{3}$ \\
\hline cross-bars & stūpa 2 & $18.5 \mathrm{in}$ & 20 in & $7 \mathrm{in}$ & $2590 \mathrm{in}^{3}$ \\
\hline rail-pillars & stūpa 2 & 71 in & 16 in & $10 \mathrm{in}$ & $11360 \mathrm{in}^{3}$ \\
\hline coping-stones & stūpa 2 & $17 \mathrm{in}$ & $77 \mathrm{in}$ & $14 \mathrm{in}$ & $18326 \mathrm{in}^{3}$ \\
\hline
\end{tabular}


Thirdly, we could think of the vedika in simple material terms. Table 2 lists the generalized size of the vedika pieces. It may be reasonable to suggest that because of their weight and sheer size the coping-stones were worth more as objects than the other pieces. To place them in position above the rail-pillars required a considerable amount of workforce and effort to cut the stone, move it, and, finally, place it. As such, coping-stones were also the fewest. Coping-stones were probably the most expensive to commission for the architectural program for these reasons.

Likewise, we can relatively judge the value of each piece based on number and volume. The volume of pieces negatively correlates with the number of the pieces: the heaviest pieces are the fewest, while the cross-bars, being the lightest, were the most abundant. The presence of our hundreds of donation inscriptions upon these pieces may have indicated the relative value of each donation. Even if the donations themselves were not specifically designated for 'a cross-bar' or 'a rail-pillar', the donation record inscribed on the pieces may have functioned as some kind of receipt or written 'thanks' for the donation correlative to the fragment upon which it is inscribed.

The coping-stones are by far the heaviest pieces according to volume $\left(\mathrm{in}^{3}\right)$ and are a great example of donation power. Their size is nearly twice that of a rail-pillar and almost six times that of a crossbar. If the funds for the donation of a coping-stone were not for the symbolic pride of donating the biggest, rarest piece of a religious structure, then the sheer cost of transportation of the massive stone in itself required significant funds. It seems unlikely that the labor cost was absorbed as overhead by the samgha. Whoever could donate such a rare item undoubtedly received the intangible benefits associated with the ability.

TABle 3 Vedikā Pieces and Donation Groups

\begin{tabular}{llll}
\hline \hline Feature & Location & Volume & Largest Donation Group \\
\hline cross-bars & stūpa 1 & $3038 \mathrm{in}^{3}$ & Laity \\
\hline rail-pillars & stūpa 1 & $35626.5 \mathrm{in}^{3}$ & Laity \\
\hline
\end{tabular}




\begin{tabular}{llll}
\hline Feature & Location & Volume & Largest Donation Group \\
\hline \hline coping-stones & stūpa 1 & $63360 \mathrm{in}^{3}$ & Monastic \\
\hline cross-bars & stūpa 2 & $2590 \mathrm{in}^{3}$ & Monastic \\
\hline rail-pillars & stūpa 2 & $11360 \mathrm{in}^{3}$ & Monastic \\
\hline coping-stones & stūpa 2 & $18326 \mathrm{in}^{3}$ & Monastic \\
\hline
\end{tabular}

Comparing donor groups with what was donated, we may be able to tentatively obtain a sense of intention and order amongst the evidence. For instance, the monastic community is responsible for most of the coping-stone donations. $77 \%$ of them were donated by members of the monastic community as found on stüpa 1's ground vedik $\bar{a}$, an overwhelming percentage when compared to other donor frequencies. It may be justified to say that the monastic community possibly had a predetermined pursuit to donate coping-stones, whether they were the most soteriologically auspicious pieces, the most expensive pieces, or just the largest and most symbolic of giving power due to their size and architectural symbolism. The same cannot be said about the rail-pillars, as the laity were the major donor group, but at only 50\%, not as overwhelming of a majority as the monastic group was for coping-stones. Even though we can see the donations of the monastic community, it is still difficult to determine much else about the monastics themselves since the information derived from the inscriptions is limited. This insight is one way to begin to tease out new observations from the restricted dataset.

The inscriptions themselves provide information about the relative values of the architectural pieces. In some of the older inscriptions, occasionally the donation itself is mentioned, being that of a cross-bar (suci), pavement slab (silā), or even rail-pillar (thabba). Eventually, this terminology fell out of favor and dropped from the inscriptional records for unknown reasons. It is certainly possible that the donations themselves included more than the architectural fragments, but this information is not available to us. Many factors could have, of course, changed relative value, such as market forces, time of year, or even whether or not the pieces were inscribed with 
ornamentation or not. Nevertheless, each of the inscriptions studied in both of the Generations contain the same components. For instance, railings from Sanchi stūpa 2 contain bas-relief images, which could make their value different from, say, Sanchi stüpa 1's vedikā, which only has ornamentation on the toranas and on the berm vedika Fortunately for our estimated valuation, all inscriptions from each of the two Generations are of the same variety. That is, all of the inscriptions from Generation 1 are donated vedika fragments that contain bas-relief images, whereas Generation 2 has no such relief images. Thus, the relative valuation proposed here functions using the same variables. ${ }^{26}$

The following donation from stūpa 1 may hint at the price of a single donation on the ground vedik $\bar{a}$ :

Sanchi Inscription $294^{27}$

(Late first century BCE)

L1 vejajasa gāmasa dānaì

'A gift of the Vejaja village'. ${ }^{28}$

26 In some cases, inscriptions are placed inside the vedikās, facing the stūpa. This may potentially change how the locals at the time viewed the value, either actual value or spiritual value, of the inscription itself. After studying this angle for several years, I am not at this time able to delineate any clear difference in value between these 'inside' inscriptions versus the much more plentiful 'outside' inscriptions. The only difference seems to be that more elite monastic donors have their inscriptions appear 'inside' facing the stūpa and that there are dramatically fewer 'inside' inscriptions altogether. I wrote about this distinction in my M.A. thesis at the University of Texas at Austin, but have not chosen to pursue this line of inquiry for publication at this time.

27 The number referred to here and throughout referred to Tsukamoto, Indo Bukkyō himei no kenkyū, vol. 1-3. For reference, I will also cite Marshall, Foucher, and Majumdar, The Monuments of Sāñchī, inscription number as well with the abbreviation MM. MM 308.

28 All translations are my own. 
If it takes the accumulated funds from one single village to account for a single vedik $\bar{a}$ piece, then we may infer that it was expensive relative to donations for items we currently do not have records of, such as food, clothing, or candles. Alternatively, perhaps the village of Vejaja was relatively poor, or the village itself was disinterested in giving to the Buddhist community and raised only a few donations. Whatever the case may be, the comparison between this inscription, on a single rail-pillar, to others is worthwhile to consider.

One comparison is to a set of three continuous donations by the merchant Samika and his son Siripāla. Also from stūpa 1, they read:

Sanchi Inscription 186, 187, $188^{29}$

(Late first century BCE)

\section{L1 samikasa vānikasa putasa ca sa siripälasa dānaì}

'A gift (of three cross-bars) by Samika, a merchant, along with his son Siripāla'.

Samika, being a pious and wealthy merchant, probably desired to donate a fixed sum towards the construction of a stūpa vedikā. However, his available funds were perhaps not enough to acquire a rail-pillar (as the accumulated funds of the Vejaja village, was, in contrast). One speculation is that instead of giving just one cross-bar, Samika was determined to donate his entire sum, earning him three cross-bars but not a rail-pillar, which could have been out of his 'price range'. These identically inscribed cross-bars were assembled and placed into position during the same generation. Samika probably did not visit the site more than once to donate (or was solicited at his home more than once), but gave a set sum, more than enough for one cross-bar but not quite enough for a rail-pillar. Thus, three cross-bars, all lined up in a row, are in his name.

Another inscription from stūpa 1 during the same generation helps to further establish the relative value of the donated architectural pieces:

29 MM 200-202. 
Sanchi Inscription $161^{30}$

(Late first century BCE)

\section{L1 subāhitasa gotiputasa rājalipikarasa dāna}

'A gift of the royal-scribe Subāhita, a Gotiputa'.

Subāhita's inscription is marked on a rail-pillar, the same railpillar as the Vejaja village inscription. It is the donation of a royal (räja) scribe, a unique mercantile title. There are no other royal inscriptions on the ground vedik $\bar{a}$, although several other inscriptions reflect donations of other scribes. Lastly, Subāhita's name is in the same genitive case as Gotiputa, a person known from reliquary inscriptions found in stüpa 2. Gotiputa was the teacher of many other prominent monastic teachers in this region and bore the epithet sapurisa. ${ }^{31}$ Gotiputa, as explained elsewhere, is a metronymic ${ }^{32}$ to describe a group potentially linked by mutual maternal ancestry, possibly connoting brāhmaña status via a brābmaña mother. ${ }^{33}$ There were likely several individuals bearing this metronymic in and around Sanchi in the first century BCE, including the charismatic leader whose relics are enshrined. There could be several ways to translate sapurisa, but Majumdar opted for 'saint' to harken at the literal translation of the Sanskrit, sat-puruṣa (Pāli sappurisa), mean-

\section{MM 175.}

31 In Findly's discussion of a sappurisa (sapurisa in the Sanchi Prakrit), the good person 'gives a gift respectfully, with his own hand, with consideration, in purity, and with a view to the future' (Findly, Dāna, 192). The use of the title at Sanchi seems to fit accordingly with the model described by Findly. The sapurisas of old, namely those whose relics are enshrined in stüpa 2, acted for the benefit and welfare of their whole community, as their titles suggest.

32 Milligan, 'Of Rags and Riches', which updates Willis, 'Buddhist Saints in Ancient Vedisa'.

33 On this subject, see Falk, 'The Tidal Waves of Indian History'. The famous Gotiputa who is enshrined is also called a member of the brāhmaṇaical Kaundinya gotra as stated in the reliquary inscription from Andher stüpa 2. 
ing 'a good man'. ${ }^{34}$ Majumdar also takes Subāhita, the scribe, as being the son of Gotiputa, but I take it to mean that Subāhita is one of several Gotiputas in a group and not an individual with the personal name Gotiputa. Perhaps the inscription could be translated as: 'A gift of the royal-scribe Subāhita, who is [born] of a Gotiputa'. This rendering would maintain the genitive case while still also keeping the reference to the sapurisa Gotiputa. It could be equally possible to translate the compound 'Gotiputa' as a genitive tatpurusa, 'son of [a] Goti', which does not change my argument.

Considering Subāhita's status seems to be somewhere between a royal mercantile at the very least and a relative of a famous sapurisa in the area, on the other hand, Subāhita was probably one of the most affluent and/or socially well-connected members of the immediate donor community. Subāhita's considerable status-and the fact that he likely was a brähmana since his famous enshrined relative was a brābmana-supports the idea that rail-pillars, in addition to copingstones, held more status-and perhaps value-than cross-bars, thus indicating that the architectural pieces, which were the result of donation, could be telling as to the donor's status. I posit that this architectural data points to an emergent donation habit that reveals an increased cooperative effort on behalf of the organizers-namely the monastics-to muster the resources, workforce, and financial sum to erect such a massive monument that is stūpa 1's vedikā.

TABLE 4 Adjusted Equity Valuation

\begin{tabular}{llll}
\hline Era & Monastic Community & Mercantile Community & Everyone Else \\
\hline Generation 1 & $90 \%$ & $.7 \%$ & $9 \%$ \\
\hline Generation 2 & $64 \%$ & $8 \%$ & $29 \%$ \\
\hline
\end{tabular}

34 Marshall, Foucher, and Majumdar, The Monuments of Sāñchì. Elsewhere, I proposed that this is not a monastic title but rather a title given to exemplary persons who are usually also exemplary donors. See Milligan, 'Of Rags and Riches'. 
We may tentatively assess the value-meaning the adjusted equity-of the entire constructed environment at Sanchi based on these figures and concepts. Over the past many years, I have been able to re-read and re-investigate the paleography, content, and connections between all of the Sanchi donation epigraphy. ${ }^{35}$ One major conclusion, as previously described, is that all the early epigraphy as found on the vedikās, ground or otherwise, from Sanchi stüpas 1 and 2 may be tentatively and relatively dated into two Generations based on several factors. In Generation 1 at Sanchi, which includes the ground vedikā of stūpa 2 and the upper vedikā from stūpa 1, there are 244 useful and readable inscriptions. Of these 244 extant separate inscribed architectural pieces, there were 209 individual donors. Analyzed all together, these 209 individual donors were responsible for a total accumulated spatial volume of 49,605,000 in ${ }^{3}$-an enormous amount, to be sure. That calculates to about 4778 in $^{3}$ contributed on average per donor-or one theoretical 'share'. To put forth a valuation on that Generation of donors, we may divide up the pieces according to self-identifying occupation. Approximately $90 \%$ of Generation 1's volume-meaning $90 \%$ of the total constructed mass - from about the middle of the first century BCE was funded by self-identified ordained members of the Buddhist samgha. Surprisingly_or not-under $1 \%$ of the total spatial volume was funded by members of the mercantile community while the rest-just $9 \%$ total—was funded by 'everyone else'.

If we use the same calculation to assess the second Generation of donors at Sanchi, which primarily includes the enormous ground vedikā from stūpa 1, those pie-chart numbers are different. In Generation 2, which has a behemoth total of 90,480,000 in ${ }^{3}$ worth of spatial volume, the average donated share was more than four-times the volume as it was in Generation 1. Further, the division of funded spatial volume shows that the monastic community itself, although still a significant contributor, dipped in percentage to only $64 \%$ while the mercantile community rose to $8 \%$, leaving $29 \%$ of the construct-

35 Milligan, 'The Development and Representation'; Milligan, 'Five Unnoticed Donative Inscriptions'; Milligan, 'Of Rags and Riches'. 
ed landscape to be funded by 'everyone else'. This built landscape valuation change over time, from the middle to the later decades of the first century BCE, meaning one round of funding later, demonstrates that the Buddhist samgha had a shifting relationship towards the donation of their funds. What may be the reason for taking a 'step back'? I believe modeling the data and including a few new variables may significantly improve our vision.

\section{The Model}

Many of the inscriptions not only identify the donor's name, occupation, lineage, relationships, and so on, but also-as Schopen astutely observed-their natal residence, which could be anything from a small town to large urban centers famously known throughout the subcontinent. Nearly half of all donors in Generation 1 and nearly three-fourths in Generation 2 self-identify as being from a nonlocal place of origin. Given these enormous percentages of donors' self-identification according to location, I took the liberty to assume that all donors who do not list a non-local location are, in fact, actually, local from Sanchi or close enough that they did not bother listing their home residence. ${ }^{36}$

TABLE 5 Monastic Donation Compared to Average Donation

\begin{tabular}{llll}
\hline Era & Monastic & Local Monastic & Non-Local Monastic \\
\hline Generation 1 & $116 \%$ & $122 \%$ & $108 \%$ \\
\hline Generation 2 & $124 \%$ & $67 \%$ & $155 \%$ \\
\hline$\Delta$ & Slight increase & Major decrease & Major increase \\
\hline
\end{tabular}

36 For a detailed look at local vs. non-local donors, see Milligan, 'Of Rags and Riches'. 
Examining the monastic community using this variable is extremely revealing. Between Generation 1 and Generation 2, the monastic community's average donation, when compared to the average amongst all donors, rises from $116 \%$ of the average share (in terms of volume) to $124 \%$, indicating that the monastic community, despite contributing less overall in terms of percentages was donating larger portions. There is, however, a major discrepancy when we separate the local monastic donors from the non-local monastic donors: from Generation 1 to Generation 2, the average local monastic contribution significantly decreases from $122 \%$ to just $67 \%$. Meanwhile, the donation potential of non-local monastics rises from $108 \%$ to a staggering $155 \%$, thus strongly indicating a shift from local monastic donation to non-local monastic donors.

Is there any plausible explanation for these significant shifts in donation patterns? One answer potentially lies in a significant change in fundraising economic perspective. During the initial funding state of Generation 1, the local samgha itself closed the funding gap by 'filling in the blanks' with its wealth and resources. As a result, the amount of adjusted equity the samgha possessed of Sanchi during Generation 1 was enormous-approximately $90 \%$ of the available equity. We see this also in the potential donation averages. It was the local monastics who possessed the largest donations during Generation 1, whereas in Generation 2 it was non-local monastics by far. In other words, between these two Generations, we have an observable phenomenon explained in a basic anthropological model of the 'core' and 'periphery'. As time went on, the samgha still felt the need to close the funding gap using its own funds. However, by Generation 2, the samgha did not need to draw upon its local resources to construct and expand on Sanchi. Instead, they drew funds mostly from non-local monastics, thus also representing an extension of the immediate donation network. This model may be summarized as gradual material expansion from within, which is akin to modern-day venture capitalism 'bootstrapping', whereby a group of founders and co-founders of a company primarily utilize their own financial and donation resources to close the initial funding gap in order to give their company a firm standing from which to incorporate and produce goods. 


\section{Conclusion}

Material expansion from within-also known as bootstrapping in my model-is primarily observable during the Early Historic period with a large amount of evidence from a single location examined over a set time frame. One concluding argument concerns the material differences between the monuments in Generation 1 and Generation 2. During the first Generation, the amount of calculable volume per share was just around 4,778 in ${ }^{3}$, whereas in the second Generation, the volume per share was approximately $19,704 \mathrm{in}^{3}$. Given the sheer size difference in the monuments under consideration, this is not at all surprising. What is surprising is the observable number of shares in each of the two Generations.

I calculate shares by using what I call the donation potential formula, that is, the average amount of volume contributed per donor. One single share of equity at Sanchi during the first century BCE is equal to the average amount donated by all donors. The fascinating difference between the two Generations is that, for some reason, the number of total shares decreases substantially. In Generation 1, there are approximately 1,038 shares of equity, whereas in Generation 2 there are only 459 . The take away from this small micro-analysis of averaged-shares at Sanchi displays the interesting, and somewhat backward, discordance between the number of shares and an inferred share value. Put simply, as the raw number of equity-shares at Sanchi decreased, the approximated value of the shares increased dramatically.

Analyzing these phenomena together, we are left with these conclusions:

1. Monastic (samgha) donors were responsible for a disproportionately large amount of the donations across two Generations at a growing built landscape.

2. Over time, local monastic donors gave way to non-local monastic donors to close the funding gap.

3. The number of available donated shares decreased over time while their value increased. 
These three significant insights into the patronage of Sanchi during the first century BCE demonstrates the complexity of 'joint ownership' over constructed, public-use monuments like stüpas. Even though the samgha seemed to relinquish some power over Sanchi through their donation efforts, it remained the preeminent patron to its efforts in a donation process I identify as bootstrapping.

To return to the idea that the samgha was 'exactly like the laity' as it pertains to their status in donation epigraphy, as seen here with the bootstrapping of Sanchi's ritual monuments, Professor Schopen may be more correct than he ever expected. Long ago, he rightly brought to light the problematic nature present at many sites where monastic donors are the group reaping many if not most of the 'merit' or reputation from the donation. For example, Schopen argued:

[i]n fact, if we stick to what we can actually know [...] we know for certain from inscriptions that from ca. 150 B.C.E. - that is to say, from our earliest knowable donative inscriptions and well before we can have any definite knowledge of the textual tradition-monks and nuns formed a substantial proportion of those involved in donative, merit-making activities connected with the stüpa cult and, somewhat later, the cult of images... ${ }^{37}$

More or less, the data and analysis presented above defend Schopen's old but astute observation, which, at the time, was based on a somewhat limited scope of the epigraphic corpus. The business ventures of early Indian monastic Buddhists outside of Magadha were either inspired by lay business practices or were the inspiration for business ventures involving the joint-funding and construction of large, official buildings with a variety of intended uses.

37 Schopen, Bones, Stones, and Buddhist Monks, 31-32. 


\section{Bibliography}

Abbreviations

AŚ Arthaśāstra. See Bibliography, Sources, Olivielle.

MM Inscriptions in The Monuments of Sāñchi. See Bibliography, Sources, Marshall, Foucher, and Majumdar.

\section{Sources}

Cornwall, Jeffrey. Bootstrapping. New York: Prentice Hall, 2010. Dehejia, Vidya. 'The Collective and Popular Bases of Early Buddhist Patronage: Sacred Monuments, 100 BC-AD 250'. In The Powers of Art, edited by Barbara Stoler Miller, 35-45. New York: Oxford University Press, 1992.

Falk, Harry. 'The Tidal Waves of Indian History'. In Between the Empires, edited by Patrick Olivelle, 145-68. New York: Oxford University Press, 2006.

Findly, Ellison Banks. Dāna: Giving and Getting in Pali Buddbism. Delhi: Motilal Banarsidass Publishers, 2003.

Grichnik, Dietmar, Jan Brinckmann, Luv Singh, and Sophie Manigart. 'Beyond Environmental Scarcity: Human and Social Capital as Driving Forces of Bootstrapping Activities'. Journal of Business Venturing 29, no. 2 (2014): 310-26.

Jayawarna, Dilani, Oswald Jones, and Allan Macpherson. 'New

Business Creation and Regional Development: Enhancing

Resource Acquisition in Areas of Social Deprivation'.

Entrepreneurship 62 Regional Development 23, no. 9-10 (2011): 735-61.

Jones, Oswald, and Dilani Jayawarna. 'Resourcing New Businesses:

Social Networks, Bootstrapping and Firm Performance'. Venture Capital: An International Journal of Entrepreneurial Finance 12, no. 2 (2010): 127-52.

Marshall, John H., Alfred Foucher, and Nani G. Majumdar. The Monuments of Sāñchi. Vol. 1-3. Delhi: Swati Publications, 1982. McClish, Mark. The History of the Arthas'āstra: Sovereignty and 
Sacred Law in Ancient India. Cambridge: Cambridge University Press, 2019.

Milligan, Matthew D. 'The Development and Representation of Ritual in Early Indian Buddhist Donative Epigraphy'. Pacific World:Journal of the Institute of Buddhist Studies 15 (2013): 171-86.

_- - 'The Economic Power of Women in Early South Asian Buddhism'. The Indian Economic E'Social History Review 56, no. 1 (2019): 1-24.

- - - 'Five Unnoticed Donative Inscriptions and the Relative Chronology of Sanchi Stūpa II'. Annual Report of the International Research Institute for Advanced Buddhology 18 (2015): 11-22.

- - - 'Of Rags and Riches: Indian Buddhist Patronage Networks in the Early Historic Period'. Ph.D. dissertation, The University of Texas, 2016.

Olivelle, Patrick. King, Governance, and Law in Ancient India. Kautilya's Arthaśāstra. Oxford: Oxford University Press, 2013. Patel, Prankaj, James Fiet, and Jeffrey Sohl. 'Mitigating the Limited Scalability of Bootstrapping through Strategic Alliances to Enhance New Venture Growth'. International Small Business Journal 29, no. 5 (2011): 1141-58.

Roy, Kumkum. 'Women and Men Donors at Sanchi: A Study of Inscriptional Evidence'. In Position and Status of Women in Ancient India, edited by L. K. Tripathi, 209-23. Varanasi: Banaras Hindu University, 1988.

Schopen, Gregory. Bones, Stones, and Buddhist Monks. Honolulu: University of Hawai'i Press, 1997.

-_- Buddhist Monks and Business Matters. Honolulu: University of Hawai'i Press, 2004.

- - - ' 'Doing Business for the Lord: Lending on Interest and Written Loan Contracts in the Mūlasarvāstivāda-Vinaya'. Journal of the American Oriental Society 114, no. 4 (1994): 527-54.

- _ - 'The Lay Ownership of Monasteries and the Role of Monks in the Mūlasarvāstivādin Monasticism'. Journal of the International Association for Buddhist Studies 19, no. 1 (1996): 81-126. 
- - - 'Monastic Law Meets the Real World: A Monk's

Continuing Right to Inherit Family Property in Classical India'. History of Religions 35, no. 2 (1995): 101-23.

- - - 'The Ritual Obligations and Donor Roles of Monks in the Pali Vinaya'. Journal of the Pali Text Society XVI (1992): 87-107.

- - - 'What's in a Name? The Religious Function of the Early Donative Inscriptions'. In Unseen Presence: The Buddha and Sanchi, edited by Vidya Dehejia, 58-73. Mumbai: Marg Publications, 1996.

Shaw, Julia. Buddhist Landscapes in Central India. London: The British Association for South Asian Studies, 2007.

- - - 'Nāga Sculptures in Sanchi's Archaeological Landscape'. Artibus Asiae 64 (2004): 5-59.

Taddei, Maurizio. 'The First Beginnings: Sculptures on Stupa 2'. In Unseen Presence, edited by Vidya Dehejia, 77-91. Mumbai: Marg Publications, 1996.

Tsukamoto Keishō 塚本啓祥. Indo bukkyō himei no kenkyū インド 仏教碑銘の研究 [A Comprehensive Study of Indian Buddhist Inscriptions]. Vol. 1-3. Kyoto: Heirakuji Shoten 平樂寺書店, 1996.

Willis, Michael. 'Buddhist Saints in Ancient Vedisa'. Journal of the Royal Asiatic Society Third Series 11, no. 2(2001): 219-28. 